\title{
Professor Kazimierz Pelczar (1894-1943) Founder of an organised campaign against cancer in Vilnius 85 years ago
}

On a certain frosty day of winter in 1931 a group of Vilnius residents, having faith in a better future for the treatment and care of cancer patients, founded a hospital with 10 beds on one of the floors of an old peoples'home. This was 85 years ago. The founder was Professor Kazimierz Pelczar who became the institute's Director until his death in 1943.

\section{Who was Professor Kazimierz Pelczar}

The Professor was a graduate from the Faculty of Medicine at the Jagiellonian University in Krakow, subsequently becoming a Professor at the Vilnius Stefan Batory University and the Dean of the Faculty of Medicine together with being the Departmental Head of General and Experimental Pathology. He was a profoundly knowledgeable scientist of many talents and a tireless experimenter, researcher, gifted teacher and friend of young medical students. He also successfully initiated and organised many healthcare projects and was regarded as a doctor by vocation and praised by his many grateful patients.

Professor Konrad Gorski from the Stephen Batory University in 1934-1939, and member of the Polish Skills Academy (later Polish Academy of Sciences), along with being one of Professor Pelczar's biographers wrote; according to the dictum of speaking well of the dead some people say 'only good things', regardless of whether they are true or that with the best of intentions are contrived, but when writing about Professor Pelczar one has to use the best words possible, because he was such a comprehensively erudite personality, who radiated intelligence, was very well read and had a great living interest in the humanities. He also showed great artistic ability and was a wise social activist/ /community worker. But above all, he was a man of extraordinary kindness and goodwill, keeping to the highest ethical standards with deep moral and humanist convictions.

In his daily duties at work and outside he was always a kind and friendly person of great personal charm and culture. He had a great personal sense of mission which he fulfilled at Vilnius during 1930-1943.

Vilnius society was naturally most grateful to receive the ministrations of Professor Pelczar. People there nowadays recall him touchingly and Povilas Cibiras, a former student and Professor of the Vilnius University (deceased in 2003), remembered him fondly with tears in his eyes.

\section{Professor Pelczar's education and personality}

He was born on 2nd August 1894 at Truskawiec in the Lvov region, being the son of Zenon and Maria Krasnodebsky; a prominent Polish intelligentsia family with connections to Cracow often noted in encyclopaedias. His wife was Janina Mossorow, a woman of captivating beauty closely related to an outstanding Polish physician, Joseph Dietl, who was a pioneer of Polish Balneotherapy, a Professor and Rector of the Jagiellonian University and also a mayor Cracow. Professor Pelczar's father was Professor Zenon Pelczar, the owner of the Truskavwiec sanatorium, and a respected spa physician expert on the healing properties of water from Drohobych; being also the author of several publications, such as 'Truskawiec as a medicinal institute,'A guide to Spas' and '1827-1927; a Truskawiec centenary'. After his death in 1934 an obituary in a medical journal wrote: 'a doctor by the grace of God'.

Professor Zenon Pelczar had succeeded in awakening and developing his son's interest in the natural sciences and medicine. After graduating with honours from high school in Drohobych (1912), Kazimierz enrolled to the Faculty of Medicine at the Jagiellonian University in Cracow. However, after two years his studies were interrupted by the outbreak of World War I and he was drafted into the Austrian army and sent to the front. For active battle service he was awarded the Silver Medal but on February 23rd 1915 he was taken prisoner by the Russians. He then worked at the Catholic Hospital in Kiev, in the Samara region, fighting against typhus fever and in Bugieraslaw he was made deputy chief doctor at the prisoner of war camp. In 1919, he joined with the Polish army in eastern Russia, where he was deputy chief physician of the sanitary train, working under Professor Witold Orlowski. He returned to Poland via China and Japan. From the 1st July 1920, he took part in the Battle of Warsaw fighting in the ranks of the army under General Wladyslaw Sikorski for which he received the Cross of Valour.

In all he spent 6 years in Russia and closely witnessed the Russian October Revolution, working in medical healthcare 


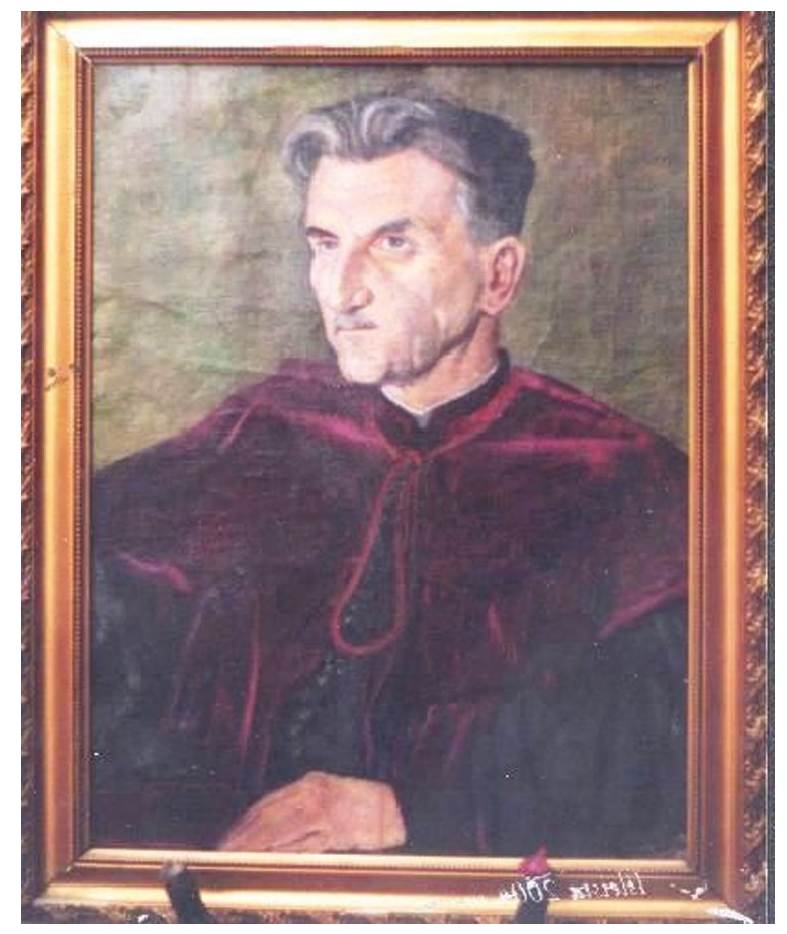

A portrait of Professor Kazimierz Pelczar by Timothy Niesiolowski

and tending to the needs of Russian people which in fact caused his return home to be delayed. In 1920, he finally returned to his beloved Cracow and resumed his studies at the Jagiellonian University (JU). His outstanding ability and passion for scientific work caught the attention of Professor Charles Klecki, where as a student he was appointed junior assistant in the JU Department of General and Experimental Pathology. He was also the President of the Fraternal Help for Medics and helped set up a college printing press and catering facility.

On January 24th 1924, he graduated and on 28th October 1925 became qualified receiving a $\mathrm{PhD}$ degree in the Medical Sciences. After completing his habilitation on September 30th 1930, he was appointed Senior Assistant. He deepened his knowledge by working at various scientific departments. In the Department of Medical Chemistry under Professor Leo Marchlewski he studied metabolism.

His special interest was however oncology and in 1927 to 1928 he was posted to Berlin, thanks to a state-scholarship, where under Professor H. Auler he trained in haematology, transplantation of cancer tissues and their ex-vivo culturing in 1928. In 1928, he studied cancer biology at the Pasteur Institute in Paris and then went on to study cancer resistance under Professor Claudius Regaud at the Radium Institute; also in Paris. He published three scientific papers arising from this work of which Professor Auler was co-author in two. At the VII Congress of Pathologists in Wiesbaden he gave a lecture and took part in an international congress in London on cancer.
Upon returning home, he worked on cancer resistance and prepared for his Habilitation; the dissertation being 'Serological resistance in cancer' which was announced in 1929. At the second sitting of his Habilitation degree he was absolved from giving his Habilitation lecture and on 2nd July 1929 he was awarded the veniam legendi (right to teach) for general and experimental pathology according to a resolution passed by the Faculty of Medicine at the JagielIonian University which was approved on 9th September of the same year.

Shortly before being awarded the veniam legendi, he received a letter from a friend in Vilnius informing that he was being considered for the vacant post of Director of the Pathology Department at the Stephen Batory University which had just been announced by the faculty commission who were unsure of his approval. He then received a formal invitation to apply for the post and Professor Sergei Schilling, a commission member, asked him to send in his curriculum vitae. He was in fact one of four candidates.

From the commission minutes and later in the Council of Polish Ministers conclusion, it was stressed that Dr K PelCzar's work showed a great versatility of interest, a hallmark of a good pathologist, and a wide experience of research methods; but most importantly an in-depth knowledge of medical chemistry. These features distinguished his application from the other candidates, where his work was characterised by originality and great erudition pointing towards a critical and precise mind but also one which is not without the vitality and conscientiousness required to perform valuable scientific endeavour.

\section{Chair of Pathology at the Vilnius University}

In 1930, Associate Professor Kazimierz Pelczar was appointed to the Stefan Batory University receiving the title of Professor and Head of the Department of General and Experimental Pathology at the Faculty of Medicine. Undoubtedly, his scientific interests and versatile mind had predestined him for scientific work and teaching.

After arriving in Vilnius, he found that the Department was insufficiently equipped for any scientific research as well as the building conditions being cramped. He thus began to redecorate and apply for building loans along with fitting out a library. This young scientist prioritised cancer research, believing that a cure can be discovered and thereby in his surroundings/environment he found a wide field of action, understanding and collaboration.

His scientific research covered very extensive areas where difficult issues were courageously confronted. He created around himself a congenial and fruitful atmosphere for budding young scientific talent, with his pupils being often later appointed to prestigious posts; for instance Professor Jerzy Olszewski a researcher at the University of Toronto, Nicholas Beklemiszew a member of the Soviet Academy of 




The building at 6 Plock Street where the Cancer Research \& Clinical Centre was located (present state)

Sciences, Jerzy Sztachelski the Health \& Welfare Minister in post-war Poland, Stasys Cepulis the Director of the Department of Dentistry at the University of Kaunas. In 1937-38, Professor Pelczar became Dean of the Faculty of Medicine, and was put forward as a candidate for Rector of the Stefan Batory University. In 1933, after the death of Professor Charles Klecki, he was offered the Chair of General and Experimental Pathology at the Jagiellonian University Cracow, however this he refused and opted to remain in Vilnius.

\section{Center for Cancer Research and Treatment}

As an academic, Professor Pelczar was seemingly completely absorbed in research but he was also faithful to the social traditions of his being a doctor. He observed the lack of any organised care and patient assistance for oncology. So already by 5 May 1931, and with the help of Professor Kornel Michejda and other professors, he reactivated the Vilnius Committee for Cancer and thereby a Polish Committee for Cancer was founded. By such means he organised a series of popular lectures for the citizens of Vilna about the problems of cancer and for promoting its curability. As an authentic social activist, he noted the absence of any facilities for conducting therapeutic cancer research in Vilnius. He thus decided to remedy this. As a result, by December 11931 he started to act where, literally from almost nothing, he received permission from the city municipality to use part of the small house as an establishment for care over the terminally ill at No. 6 Plock Street, modestly financed by Social Welfare.

Professor Kazimierz Pelczar also procured tenures for patient managment-staff to his establishment that included those patients bedridden and suffering from paralysis, Par- kinson's disease, rheumatism and senile dementure. Initially, patients were referred there who had long-standing cancer despite having pessimistic prognoses and where they could now obtain medical care and treatment. Under the directorship of the Professor, this establishment received patronage and finances raised from the Vilnius Committee for Cancer and was thus vigorously developed. Clinical aspects were managed by the Professor's former student, now Professor Helena Nikolaev, who proved to be an excellent clinician and organiser with facial features reminiscent of an old Madonna icon. In 1933, he opened a Radiotherapy and Histopathology Department, where in 1935 radium was purchased. This department was directed by Dr Bieloszabski trained in this field in France. Professor Pelczar was a supporter for centralising, standardising and supervising the treatment

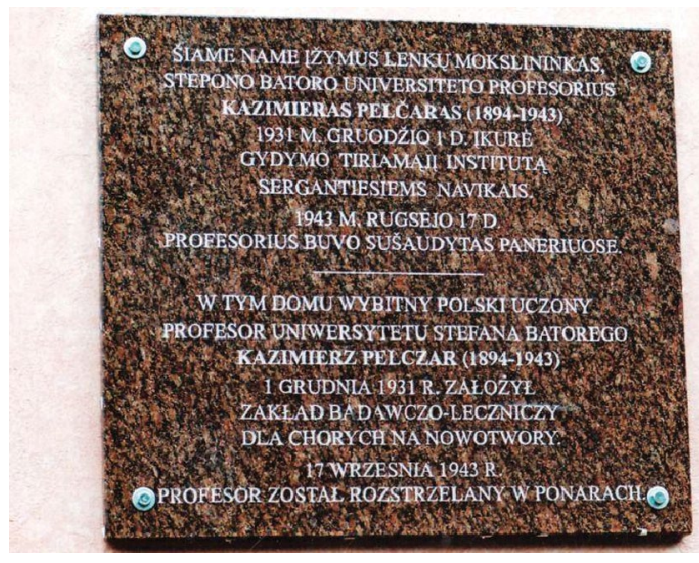

Memorial tablet set in the institute building wall 
of cancer throughout Poland. He established close links between the Vilnius Committee for Cancer and the Radium Institute in Warsaw and indeed became a member of the Radium Institute Society.

Over time, the Vilnius establishment increasingly became a more qualified institution for treating cancer patients. It later became the nucleus of the extensive and well-equipped Lithuanian Institute for Oncology. As a tribute and recognition to the achievements of Professor Pelczar, in 1973, the then Oncology Institute Director, Professor A Telycenas bestowed upon him 'The founder of Oncology in Vilnius', where through the losses of history, this title now also applies to Oncology in Lithuania.

Professor Pelczar's achievements also include his initiative and efforts to build a new Cancer Institute because the facility at 6 Plock Street had limited capacity for expansion. In 1938, the costs were estimated based on building plans at locations previously decided upon and agreed concerning its size, and being in accordance with the expansion plans of the city of Vilnius as well as those for expanding University Clinics. There was to be room for 120 beds and the plan was considered economical as modelled on the Institute in Copenhagen. It was to be built at the intersection of Konarski Street and Zakret Alley. As a thank-you for the support and partial financing of the project, Professor Pelczar wrote to the minister of social welfare;'Doctors will now be able fulfil their calling in better conditions whilst the Mister will receive the blessing of patients'.

Each day Professor Pelczar systematically examined and treated his patients where he collaborated by exchanging experience with other university clinics. What made him such an excellent doctor is best described by others working beside him or those receiving his medical care. One such co-worker, H. Maslowska, defined his attitude towards sick patients; 'He always had a smile and a word of encouragement, even when approaching the hopelessly sick, he could inspire them with hope, peace and reassurance much more than any morphine injections could ever do'. Indeed, whenever dealing with patients he had a charming smile with patients eagerly awaiting his next visit. At the sickbed he was regarded as 'someone who knew and understood everything'. The same words were used by Olga Gobryk, a Polish teacher living in Vilnius, whose sick mother was cared for by Professor Pelczar until his death in 1943. The professor also created a great working relationship with his staff who adored him according to H. Maslowska, who mentions that he gave his heart to his work. On the namesdays of 'Kaziuk Vilinius' the entire Institute celebrated the Professor with a huge cake in the shape of a heart.

On 6-8th December 1936, he organized the IV National Congress in the battle against Cancer where academics from Lithuania, Latvia, Germany and Poland took part. Dr. Bronislaw Dluska, Maria Sklodowska-Curie's sister was a member of the Congress Honorary Committee. The Congress proceedings were published the following year in the 'Cancer' journal in which the basic topics were: Organising the battle against cancer, organising hospitals and specialised centres for cancer patients together with cancer morbidity statistics. The Congress conclusions arrived at were: standardising treatment methods throughout the country, appropriate doctor training and introducing lectures on cancer into medical studies.

Professor Pelczar left a great legacy of scientific work: 85 scientific papers and monographs, not all which he managed to publish, with topics being: metabolism, vitamins, anaphylactic shock, toxicology, haematology, oncology, endocrinology and rheumatology. The Professor had great expectations of the Cephalin drug that he himself discovered exhibiting anti-inflammatory and anti-allergic action. His scientific work, however did not neglect folk wisdom, where he investigated the pharmacological effects of characterised chemical substances extracted from birch and oak trees.

Fluent in English, German, Russian and French, he frequently presented papers at international conferences, sometimes two or three in a single event. These took place at such meetings of pathologists, rheumatologists or oncologists, for example in Paris 1931, Madrid 1934, Brussels in 1936, Oxford 1937, London in 1938 and in Moscow in 1940 where often he had to travel by air. In this respect on November 1937, he was one of the few fortunate survivors of a plane crash enroute between Warsaw and Cracow.

The following is a list of Professor Pelczar's leading roles in numerous scientific and social welfare organisations:

- Departmental Head of General and Experimental Pathology at the Stefan Batory University (USB) in Vilnius;

- Deputy Professor at the Department of Bacteriology and Serology in USB;

- Departmental Head at the Vilnius Research Medical Centre for cancer patients located at 6 Plock Street;

- Dean of the Faculty of Medicine at USB;

- Member of the International Committee of Cancer in London;

- Member of the International Union Against Cancer in Paris;

- Member of the Editorial Board for the 'Acta Cancerologica' journal in Budapest;

- Reviewer of the 'Zeitschrift fur Krebsforschung' journal in Germany;

- President of the Wilno-Nowogrodzka Medical Association;

- Vice Chairman of the Radium Institute in Warsaw;

- President of the Society of Naturalists. Nicolas Copernicus;

- Board Member of the Vilnius Science Friends Society;

- Member of the Charitable Society. In addition to his scientific endeavours, Professor Pelczar also wrote many press articles and gave speeches on the radio concerning medical practice. 


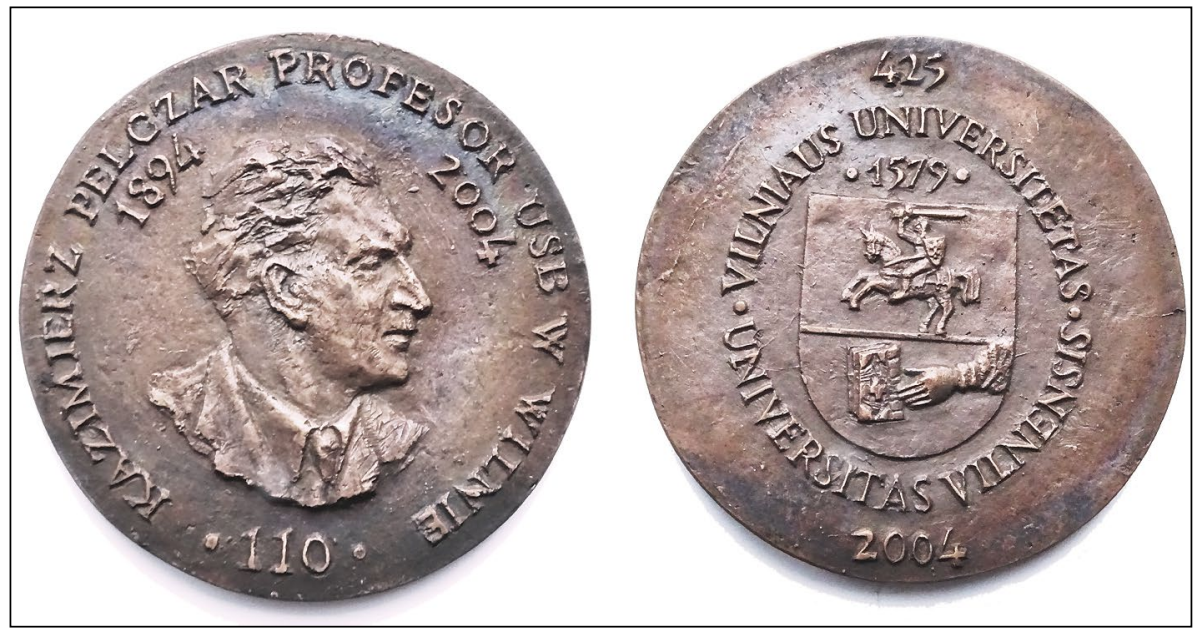

Memorial medal funded by Poles from Vilnius

\section{Center for Cancer Research and Treatment}

Upon the onset of World War Il and its approaching horrors and human miseries, the Universities of Rome, London, Paris, New York and Warsaw sent invitations for him work abroad which he nevertheless refused as he considered himself to be a citizen ofVilnius, where he remained/decided to fully share in its fate whatever the bitter dregs awaiting him could be.

Nonetheless, he continued his work and to lend any assistance required in patient treatment. Thanks to his efforts he founded the Committee for Refugees from territories occupied by the Soviet Union and managed to provide employment and succour for those so poor that were struggling to even find a piece of bread to live on.

He continued to deliver healthcare at his original establishment at 6 Plock Street, treating his fellow countrymen together with Lithuanians, Belarusians and Jews; including those under threat of being arrested by the Gestapo.

Suddenly, late in the evening September 16 1943, the Professor was taken hostage at his home after being accused by the Gestapo of being a resistance leader plotting to remove a key Gestapo agent, and on September 17 in the morning he was executed in the Ponarskim Forest. A few hours after the shooting, a telegram belatedly arrived to Vilnius from Berlin sent by eminent German scientists to try to save his life but all in vain.

Vilnius citizens cherish the memory of the Professor. Within the few last years, three conferences have been organised as follows:

- In 2001, the 70th anniversary of when the Institute was founded;

- In 2003, an entire conference devoted to the 60th anniversary of his murder where a memorial tablet was laid at the walls of the Institute;

- In 2004, a conference was held to celebrate the 110-year anniversary of the Professor's birth; a memorial medal was made.

In 2012 a street in Vilnius was named after the Professor.

\section{Christina Rotkiewicz, MD}

Vilnius, Lithuania 
